\title{
Flow resistance of individual neutrophils in coronary artery disease: decreased pore transit times in acute myocardial infarction
}

\author{
Rupert M Bauersachs, Georg Moessmer, Claudia Koch, Franz-Josef Neumann, \\ Herbert J Meiselman, Conrad Pfafferott
}

Division of Angiology, I. Medical

Department, Johann-

Wolfgang Goethe

University, Frankfurt,

Germany

R M Bauersachs

Division for Clinical

Chemistry, Technical

University Munich,

Germany

G Moessmer

Dental School,

University Würzburg

Würzburg, Germany

C Koch

I. Medical

Department,

Technical University

Munich, Germany

F-J Neumann

Department of

Physiology and

Biophysies, University

of Southern California,

Los Angeles, USA

H J Meiselman

I. Medical

Department, City

Hospital, Ingolstadt,

Germany

C Pfafferott

Correspondence to:

Dr R M Bauersachs,

Division of Angiology, I.

Medical Department, Center

of Internal Medicine,

Johann-Wolfgang Goethe

University, Theodor-Stern-

Kai 7, 60590 Frankfurt,

Germany.

Accepted for publication

9 July 1996

\begin{abstract}
Objective-To investigate single neutrophil flow resistance in coronary artery disease, including myocardial infarction before initiation of reperfusion therapy.

Design-Neutrophil flow resistance was measured in 93 subjects in five groups: (group 1) 28 patients within 12 hours after the onset of myocardial infarction, before reperfusion therapy; (group 2) 18 with unstable angina; (group 3) 13 with stable angina; (group 4) 13 age matched patients without coronary disease, and (group 5) 21 healthy volunteers.
\end{abstract}

Main parameters-Single neutrophil transit times through $8 \mu \mathrm{m}$ oligopore filters determined with a modified cell transit analyser.

Results-Leucocyte count (10\%/1) was increased in coronary disease, especially in myocardial infarction and unstable angina (mean and $95 \%$ confidence intervals for groups 1 to 5: 12.6 (11.0 to $14 \cdot 2)$, $11.3(8.5$ to $14 \cdot 1), 8.5(7.4$ to 9.6$), 8.0(6.0$ to $10 \cdot 0), 7 \cdot 0(6 \cdot 1$ to $7 \cdot 9))$. Polymorphonuclear granulocyte (PMN) flow resistance correlated negatively with white blood cell (WBC) count and was significantly decreased in coronary artery disease (CAD), especially in myocardial infarction; mean transit times (ms) for groups 1 to 5 were: $13.6(11.8$ to 15.4$), 16.9$ $(13.9$ to 19.0$), 16.9(12.8$ to 21.0$), 22.0(19.6$ to $24 \cdot 4)$, and $18 \cdot 6(15 \cdot 7$ to $21 \cdot 5)$.

Conclusion-Neutrophil flow resistance was decreased in CAD, especially in myocardial infarction before reperfusion therapy. In contrast to previous findings in reperfused myocardial infarction, the present study showed that stiffened PMNs were not yet present in the circulating blood pool. Thus a pharmacological approach aimed at suppressing leucocyte activation before or during reperfusion therapy may be feasible.

(Heart 1997;77:18-23)

Keywords: coronary artery disease; myocardial infarction; reperfusion; leucocytes.

Leucocytes play an important part in the development and prognosis of acute myocardial infarction. ${ }^{1-3}$ Experimental models of myocardial ischaemia ${ }^{4-6}$ suggested that polymorphonuclear granulocytes (PMN) con- tribute to the pathophysiological course of acute myocardial infarction (AMI). ${ }^{7-8}$ Potential mechanisms for neutrophil-mediated tissue injury include local activation of $\mathrm{PMN},{ }^{9}$ initiation and promotion of myocardial necrosis by generation of free radicals, ${ }^{10}$ and release of proteolytic enzymes from PMN granules. ${ }^{11}$ Through their interaction with platelets and the vessel wall and both local and systemic release of inflammatory mediators, granulocytes may maintain a vicious cycle that leads to tissue necrosis. ${ }^{61213}$ Stiffened neutrophils may plug areas of capillaries and further decrease microcirculatory perfusion and cause maldistribution during the ischaemic phase..$^{514}$

The relative contribution of the viscoelastic properties of granulocytes to the vascular resistance is not known for different stages of coronary artery disease (CAD). Current understanding of pathophysiological mechanisms suggests that three methodological aspects need to be considered in studies of white blood cell (WBC) flow resistance in $\mathrm{CAD}$ and $\mathrm{AMI}$.

- The interval between the onset of infarction and blood sampling. Any study of WBC properties is expected to be influenced by secondary changes occurring early after infarction, such as the well-known increase of WBC count caused by the release of catecholamines. In most previous studies, blood samples were not taken earlier than 12 hours after AMI. ${ }^{15-18}$

- Reperfusion after successful fibrinolytic therapy or percutaneous transluminal coronary angioplasty (PTCA) is expected to alter systemic WBC properties ${ }^{19-20}$ either as a side effect of therapeutic agents such as streptokinase, which increases WBC count, ${ }^{21}$ or through mediators-for example, interleukins - that are washed out into the systemic circulation during reperfusion. In most previous studies clinical details on reperfusion therapy were not provided or WBC flow resistance was measured after reperfusion therapy.

- Technical considerations. Whereas micropipette techniques allow measurement of the viscoelastic properties of single white blood cells, ${ }^{14}$ these methods are inappropriate for clinical studies, because of the limited number of cells that can be analysed. For larger scale studies, bulk filtration techniques have been employed. ${ }^{16}$ However, bulk filtration only provides information on the average white cell flow resistance and does not allow measurement of distinct 
sub-populations of cells, ${ }^{22}$ such as activated cells, which may have great impact on the microcirculation.

Recently, a new micropore technique, the Cell Transit Analyzer (CTA) has become available. ${ }^{23}$ This device allows the measurement of transit times of single red blood cells, and has been subsequently modified for the analysis of leucocyte pore transit times. ${ }^{24}{ }^{25}$ The CTA thus offers a new opportunity to study the flow resistance of single PMN and PMN sub-populations in larger groups of patients. ${ }^{26}$

The objective of the present study was to compare granulocyte flow resistance in different stages of coronary artery disease-that is, stable angina, unstable angina, and acute myocardial infarction - in order to obtain further information on microcirculatory pathophysiology during myocardial ischaemia. Given the methodological aspects mentioned above, the study was designed to $(a)$ obtain blood samples early after the onset of chest pain in patients with AMI and unstable angina, (b) before the initiation of reperfusion therapy, and (c) to employ a novel method which provides information on both the flow resistance of single cells and also on the distribution of single PMN pore transit times within a cell population.

\section{Patients and methods \\ PATIENTS}

We studied 93 patients and control subjects in this cross sectional study. Patients were admitted to a tertiary care hospital for diagnosis and treatment of chest pain. They were divided into five groups: (1) acute myocardial infarction; (2) unstable angina; (3) stable angina; (4) patient controls-patients older than 50 years who were admitted for various disorders and in whom coronary artery disease was excluded by non-invasive or invasive testing; (5) healthy controls-apparently healthy hospital personnel.

Acute myocardial infarction (AMI, group 1) was defined as a clinical history suggestive of AMI and ST elevation on admission with a later documented increase in creatine kinase activity (CK) and an increase of $\mathrm{MB}$ isoenzyme activity to above $6 \%$ of total CK activity. Diagnosis of unstable angina (group 2) required a positive coronary angiogram and at least one of the following criteria: (a) onset of angina within the preceding four weeks; $(b)$ crescendo angina, which includes more severe, longer, or more frequent attacks of angina; (c) angina at rest lasting for longer than $15 \mathrm{~min}$ utes. Patients with stable angina (group 3) had typical exertional chest pain and previously or newly angiographically documented coronary artery disease (diameter stenosis $>70 \%$ ). Exclusion criteria for all groups were as follows: surgery, myocardial infarction or disabling cerebral stroke during the last three months; coronary angiography, reperfusion therapy including fibrinolysis, shock or resuscitation before the collection of blood; and stage IV (NYHA) heart failure, type-1 or type-2 diabetes mellitus defined as either raised $\mathrm{HbAlc}$
$(>6.6 \%)$ or raised blood glucose (fasting $>120 \mathrm{mg} / \mathrm{dl}$ or random blood glucose $>200$ $\mathrm{mg} / \mathrm{dl}$ ) on admission or requiring diabetic therapy, known neoplasia, known autoimmune disease, thyrotoxicosis, sepsis, or peptic ulcer. Patients with other cardiac diseases such as dilated or hypertrophic cardiomyopathy, pericarditis, or vasospastic angina were also excluded. Blood was collected within 12 hours after the onset of pain in patients with AMI and unstable angina. All patients and subjects gave informed consent and the study was approved by the local ethics committee. In the recruitment plan, patients from all groups were included concurrently, in order to avoid any bias caused by changes in the CTA filter characteristics over time-that is, narrowing of the pore size after repeated use of a filter-or by small differences between CTA filters when the filter need to be changed.

\section{BLOOD COLLECTION AND SEPARATION OF} NEUTROPHILS

Blood was taken from groups $1,2,3$, and 4 on admission and from healthy controls (group 5) during normal working hours; all blood samples were drawn from the antecubital vein with EDTA $(1.5 \mathrm{mg} / \mathrm{ml})$ as anticoagulant. Six $\mathrm{ml}$ of blood were layered onto a two-step gradient made up of $2 \mathrm{ml}$ of Histopaque 1077 on top of $3 \mathrm{ml}$ of Histopaque 1119 (Sigma Chemie, Deisenhofen, Germany) below. After centrifugation at $700 \mathrm{~g}$ for $30 \mathrm{~min}$ at $20^{\circ} \mathrm{C}$ the lower white cell band was harvested. This fraction, which contained on average more than $95 \%$ granulocytes, was washed twice $(1000 \mathrm{~g}$ and $200 \mathrm{~g}$ for $5 \mathrm{~min}$, respectively) in filtered isotonic phosphate-buffered saline (PBS, $10 \mathrm{mM}$ phosphate, $\mathrm{pH}=7 \cdot 4$, Sigma Chemie, Deisenhofen, Germany) containing 5\% autologous platelet-free plasma. The number of PMNs was determined manually using standard haematology microscope chambers. On average, about $50 \%$ of the whole blood neutrophils was recovered.

\section{FILTRATION PROCEDURES}

White blood cell (WBC) pore transit times were measured as described previously ${ }^{25} 27$ using a filtration system that was originally developed to determine erythrocyte transit times through micropores ${ }^{23}$ (Cell Transit Analyzer-CTA, ABX, Montpellier, France). For the measurement of PMN, specially fabricated polycarbonate filters with 30 micropores with a diameter of $8 \mu \mathrm{m}$ and a length of $19 \mu \mathrm{m}$ were used. ${ }^{24}$ The CTA system employs a conductometric principle and provides both a mean cell transit time and a frequency histogram of individual cell transit times. The PMN suspension obtained by density gradient separation was resuspended in PBS to a final concentration of about $2 \times 10^{5}$ cells $/ \mathrm{ml}$. At least 1000 cells were analysed for each measurement, which was done in duplicate. The driving pressure was $4 \mathrm{~cm}$ of water; all measurements were performed at room temperature, and were completed within 2 hours after collection of the blood.

In order to sample longer transit times (up 
Table 1 Patients' characteristics in groups 1 to 5 . Mean values and 95\% confidence intervals are presented. $P$ values are shown for paired group comparisons

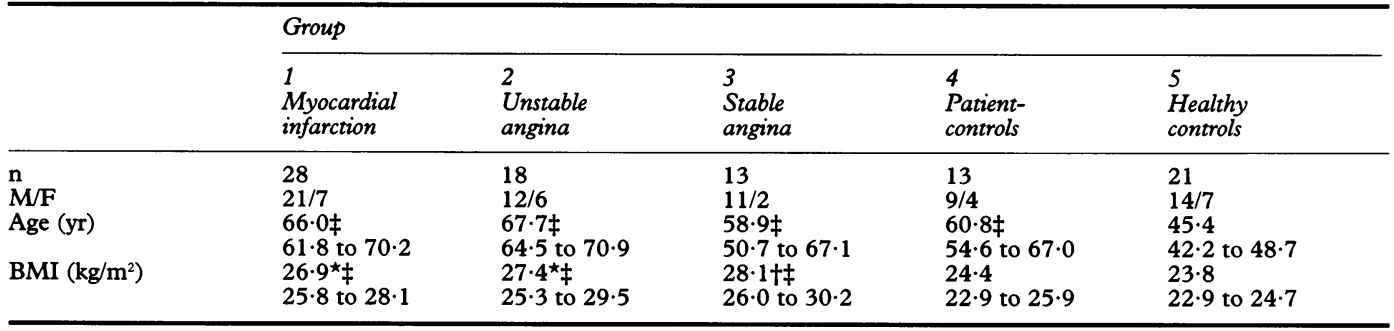

$P<0.05 v$ group $4^{\star}$

$P<0.01 v$ group $4 \dagger$ and group $5 \ddagger$.

Table 2 WBC count and PMN pore transit times. Mean values and $95 \%$ confidence intervals are presented. P values are shown for paired group comparisons

\begin{tabular}{|c|c|c|c|c|c|}
\hline & \multicolumn{5}{|l|}{ Group } \\
\hline & $\begin{array}{l}1 \\
\text { Myocardial } \\
\text { infarction }\end{array}$ & $\begin{array}{l}2 \\
\text { Unstable } \\
\text { angina }\end{array}$ & $\begin{array}{l}3 \\
\text { Stable } \\
\text { angina }\end{array}$ & $\begin{array}{l}4 \\
\text { Patient- } \\
\text { controls }\end{array}$ & $\begin{array}{l}5 \\
\text { Healthy } \\
\text { controls }\end{array}$ \\
\hline $\begin{array}{l}\text { n } \\
\text { WBC } \\
\left(10^{9} / 1\right) \\
\text { Overrange cells } \\
\text { (per } 1000 \text { PMN) } \\
\text { Mean (ms) }\end{array}$ & $\begin{array}{l}28 \\
12 \cdot 6^{\star \star}+\dagger \\
11 \cdot 0 \text { to } 14 \cdot 2 \\
55^{\star \star} \ddagger \\
43 \text { to } 67 \\
13 \cdot 6^{\star \star}+1 \\
11 \cdot 8 \text { to } 15 \cdot 4\end{array}$ & $\begin{array}{l}18 \\
11 \cdot 3 \text { t† } \\
8 \cdot 5 \text { to } 14 \cdot 1 \\
85^{\star} \text { † } \\
59 \text { to } 111 \\
16.9 \text { † } \\
13.9 \text { to } 19.9\end{array}$ & $\begin{array}{l}13 \\
8 \cdot 5 \S t \\
7 \cdot 4 \text { to } 9 \cdot 6 \\
77 \dagger \\
59 \text { to } 95 \\
16 \cdot 9 \dagger \\
12 \cdot 8 \text { to } 21 \cdot 0\end{array}$ & $\begin{array}{l}13 \\
8 \cdot 0 \\
6 \cdot 0 \text { to } 10 \cdot 0 \\
116 \$ \ddagger \\
94 \text { to } 138 \\
22 \cdot 0 \\
19 \cdot 6 \text { to } 24 \cdot 4\end{array}$ & $\begin{array}{l}21 \\
7 \cdot 0 \\
6 \cdot 1 \text { to } 7 \cdot 9 \\
82 \\
59 \text { to } 105 \\
18 \cdot 6 \\
15 \cdot 7 \text { to } 21 \cdot 5\end{array}$ \\
\hline \multicolumn{6}{|l|}{ Percentiles: } \\
\hline $25(\mathrm{~ms})$ & $\begin{array}{l}6.6^{\star \star}+\mathrm{t} \\
5.6 \text { to } 7.6\end{array}$ & $\begin{array}{l}8 \cdot 2^{\star \star} \\
6.6 \text { to } 9.8\end{array}$ & $\begin{array}{l}8 \cdot 2 \\
5.6 \text { to } 10 \cdot 8\end{array}$ & $\begin{array}{l}11 \cdot 4 \\
10 \cdot 0 \text { to } 12 \cdot 7\end{array}$ & $\begin{array}{l}9 \cdot 8 \\
8 \cdot 3 \text { to } 11 \cdot 3\end{array}$ \\
\hline 50 (ms) & $\begin{array}{l}10 \cdot 3^{\star \star}+t \\
8.8 \text { to } 11.8\end{array}$ & $\begin{array}{l}12.7 \dagger \\
10.3 \text { to } 15 \cdot 1\end{array}$ & $\begin{array}{l}12.8 \dagger \\
8.7 \text { to } 16.9\end{array}$ & $17 \cdot 2$ to $19 \cdot 3$ & $\begin{array}{l}14.7 \\
12.4 \text { to } 17 \cdot 0\end{array}$ \\
\hline 75 (ms) & $\begin{array}{l}16.0^{\star \star}+\mathrm{t} \\
13.5 \text { to } 18.5\end{array}$ & $\begin{array}{l}20.5 \dagger \\
16.5 \text { to } 25.5\end{array}$ & $\begin{array}{l}20 \cdot 7 \\
15 \cdot 3 \text { to } 26 \cdot 1\end{array}$ & $\begin{array}{l}26 \cdot 7 \\
23 \cdot 3 \text { to } 30 \cdot 1\end{array}$ & $\begin{array}{l}22.5 \\
18.8 \text { to } 26 \cdot 2\end{array}$ \\
\hline $90(\mathrm{~ms})$ & $\begin{array}{l}25 \cdot 0^{\star \star} \ddagger \\
21 \cdot 1 \text { to } 28.9\end{array}$ & $\begin{array}{l}32 \cdot 6^{\star}+ \\
26 \cdot 0\end{array}$ & $\begin{array}{l}32 \cdot 2 t \\
24 \cdot 2 \text { to } 40 \cdot 2\end{array}$ & $\begin{array}{l}42 \cdot 2 \\
37 \cdot 1 \text { to } 47 \cdot 3\end{array}$ & $\begin{array}{l}34 \cdot 3 \\
28 \cdot 4+0.2\end{array}$ \\
\hline 95 (ms) & $34 \cdot 3^{\star \star} \ddagger$ & $43 \cdot 6$ & $44 \cdot 1$ & $55 \cdot 3$ & $\begin{array}{l}28.4 \text { to } 40.2 \\
45.2\end{array}$ \\
\hline & $29 \cdot 3$ to $39 \cdot 3$ & $35 \cdot 1$ to $52 \cdot 1$ & 33.0 to 55.2 & $49 \cdot 3$ to $61 \cdot 3$ & $37 \cdot 7$ to $52 \cdot 7$ \\
\hline
\end{tabular}

$\mathrm{P}<0.05 v$ group $1^{\star}$, group $4 \dagger$, group $5 \ddagger$.

$\mathrm{P}<0.01 v$ group 19 , group $4^{\star \star}$, group $5+\dagger$.

Figure 1 (A)

Cumulative percentages on the $y$ axis are plotted against the pore transit times on the $x$ axis (in ms) for patients after $A M I$, with unstable angina, and patient-controls. (B) The same data are shown on a logarithmic scale of pore transit times.
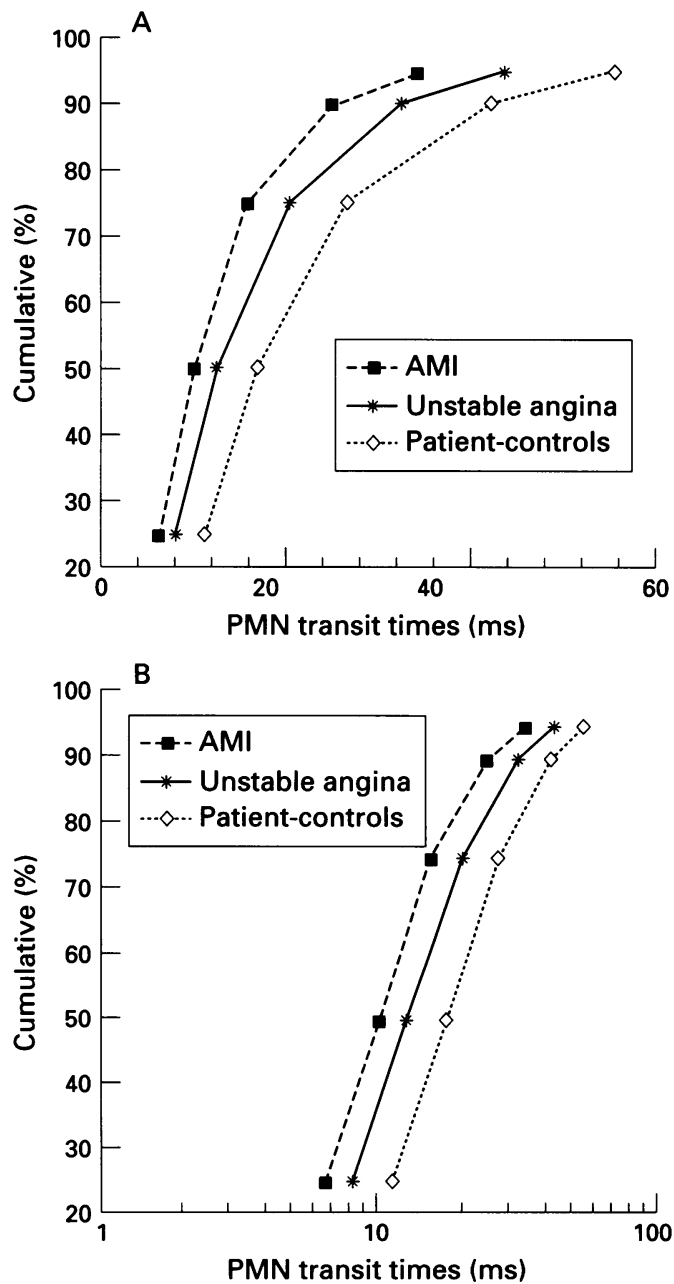

to $100 \mathrm{~ms}$ ) than for red blood cells, the original software was changed for the analysis of $\mathrm{WBC}^{25}$ and the temporal resolution was set at $0.4 \mathrm{~ms}$. Transit times are expressed as mean values and as various percentiles of $25 \%, 50 \%$ (median), $75 \%, 90 \%, 95 \%$ of the transit time distribution. If transit times were longer than the $100 \mathrm{~ms}$ sampling window, these cells were classified as "overrange" cells. When repeated measurements $(n=6)$ were performed on the same PMN samples, the coefficients of variation for the transit time percentiles ranged from 2 to $11 \%$ with $5 \%$ for mean transit times.

\section{STATISTICAL ANALYSIS}

Statistical analysis was performed using the SPSS Software package, release $2 \cdot 2$ for CDC NOS/VE. If significant differences were found with the Kruskal-Wallis test, group means were compared by Mann-Whitney $U$ tests without adjustment for multiple comparisons. Data are presented as mean and $95 \%$ confidence intervals (CI), even though not all variables were found to have a normal distribution in the Kolmogoroff-Smirnoff test; a level of $P>0.05$ was considered significant for twosided tests.

\section{Results}

Donor characteristics are shown in table 1 and leucocyte variables are shown in table 2 . The healthy control group was younger, whereas the other groups did not differ in age. The two control groups had similar BMI values, which 


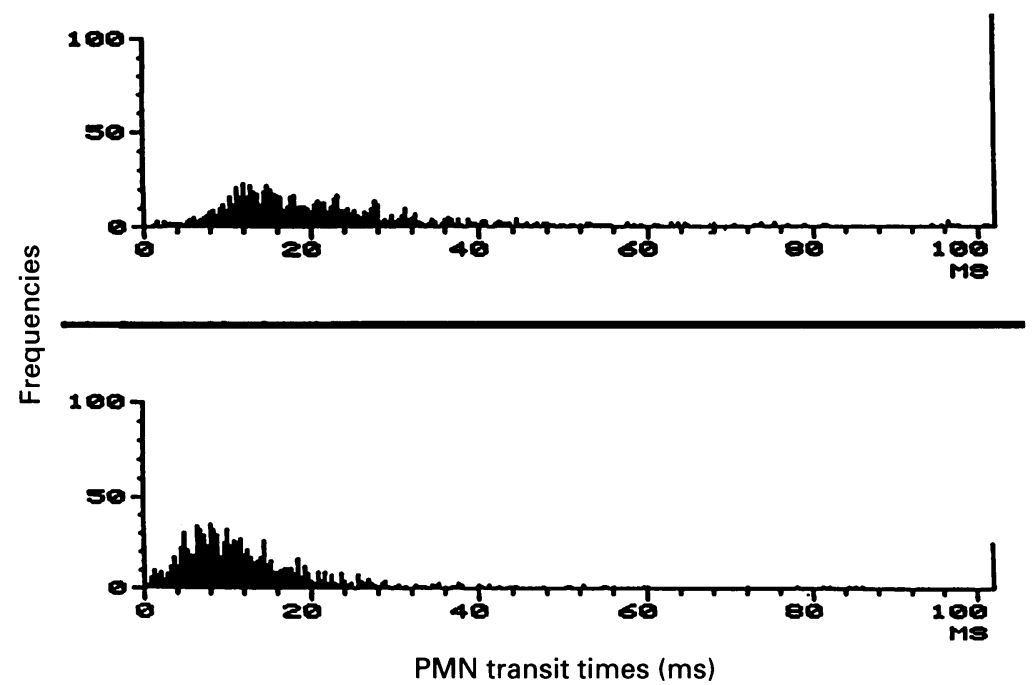

Figure 2 The two panels show typical pore transit time histograms for PMN, with transit times in $m$ s on the $x$ axis and frequencies on the $y$ axis. In the upper panel results are shown for a patient-control. The mean transit time of 886 analysed cells is $22 \cdot 3 \mathrm{~ms}$, the median was $18.0 \mathrm{~ms}$, and 113 cells were classified as overrange cells-that is, cells with transit times longer than $100 \mathrm{~ms}$. In the lower panel the results are shown for a patient with acute myocardial infarction. The mean transit time of 997 analysed cells was 12.9 $\mathrm{ms}$, the median was $10 \cdot 2 \mathrm{~ms}$, and 25 cells were classified as overrange.

were significantly less than the three CAD groups. The leucocyte count was highest in patients after myocardial infarction and was higher in the three patient groups with coronary artery disease than in the healthy controls.

\section{LEUCOCYTE PORE TRANSIT TIMES}

The Kruskal-Wallis test showed significant differences for leucocyte pore transit time variables (overrange cells, $\mathrm{P}=0.0030$; mean, $\mathrm{P}$ $=0.0028$; median, $P=0.0038 ; 95$ th percentile, $P=0.0050$ ). The results of the group comparisons are shown in table 2 and in fig 1 , and typical examples of CTA pore transit time histograms are shown in fig 2 for a patient with $\mathrm{AMI}$ and a patient control subject. In general, granulocytes from patients with coronary artery disease had shorter mean pore transit times than controls, with the shortest times in the group after AMI. Compared with patient controls (group 4), mean transit times were $38 \%$ lower for group $1(P>0.01)$ and $23 \%$ less for groups 2 and 3 ( $P>0.05$ ); group 1 also had shorter mean times compared with healthy controls $(27 \%$ lower, $\mathrm{P}>0.01)$. The cumulative percentage plots (fig 1) indicate that the differences between the groups were present across the entire distribution of transit times. When transit times were plotted on a logarithmic scale, an almost parallel shift of the curves was seen (fig 1B).

Univariate analysis showed that the number of overrange cells was negatively correlated with WBC count (overrange cells $(1 / 1000)=$ $99.6-2.3 \times$ WBC $(103 / \mu \mathrm{l}) ; r=-0.26$, $P=0.043)$. In groups 4 and 5 there were correlations with subject age (median transit times $(\mathrm{ms})=5.0+0.21 \times$ AGE (years), $r=$ $0.50, P=0.0033$ ), which did not persist if all groups were analysed together.

In summary, the study shows that the flow resistance of PMN is significantly decreased in
$\mathrm{CAD}$, especially in myocardial infarction before reperfusion therapy, and that the shorter pore transit times are correlated with the higher WBC count, which is increased in coronary disease, especially in myocardial infarction and unstable angina.

\section{Discussion}

PMN FLOW RESISTANCE

The present study investigated PMN flow resistance in patients with acute myocardial infarction, before therapeutic reperfusion and within 12 hours after the onset of chest pain. The leucocyte filtration technique that we used allowed the analysis of single white cells and sub-populations. Using this novel technique, the study is the first to demonstrate that the flow resistance of PMN from patients with acute myocardial infarction is decreased, rather than increased as anticipated from earlier studies, ${ }^{15-16}$ where a higher flow resistance (that is, poorer filterability) was observed three days after acute infarction, whereas early after the onset of pain it was not significantly different from normal. ${ }^{16}$

In the bulk filtration technique used in earlier studies, a few very rigid cells could have caused a large reduction of flow rate through the filter; however, the CTA is unaffected by pore plugging because only complete pore transits are measured. ${ }^{25} 27$ Increased rigidity days after myocardial infarction is probably caused by activation of leucocytes; such activation has been documented in animals and humans by different techniques. ${ }^{9829}$ However, there are indications that the peak in PMN activation occurs later during the course of AMI and may be accelerated by fibrinolysis. ${ }^{19}$ Thus knowledge of whether reperfusion therapy had been performed before blood sampling is critical. In the present study all samples were obtained on admission before reperfusion therapy started; therefore they are more likely to reflect the early phase of AMI before reperfusion injury has started.

After infarction, as in any tissue injury, there is an immediate shift of PMN and monocytes from tissue to the circulation ${ }^{30}$; within hours increased bone marrow release contributes large numbers of cells, including band forms, metamyelocytes, and even nucleated erythrocytes. Band forms have been found to have normal membrane viscoelastic properties and bulk filterability through $8 \mu \mathrm{m}$ pores. The observed pronounced and rapid increase of white blood cells may be attributed to a stress related increase of cortisone and catecholamine concentrations, ${ }^{31}$ both of which inhibit PMN activation. ${ }^{32}$ It may be speculated that a new population of WBC is present in the peripheral blood early after AMI, and that some of these cells are immature and less likely to be activated, as has been reported for neutrophils during the first day of AMI..$^{33}$ Recent data suggest that some PMNs become activated in evolving $\mathrm{AMI}^{74}$ and are trapped in the pulmonary or myocardial circulation, ${ }^{35}$ thus leading to a substantial increase of PMN in the myocardium during AMI. ${ }^{32} 3637$ 
For unstable angina it has been shown that there is increased leucocyte activation ${ }^{3038}$ together with increased flow resistance. During percutaneous transluminal coronary angioplasty (PTCA) an increase in PMN activation and impaired pore transit times were found in coronary sinus blood. ${ }^{39}$ In the present study, the widest variation in the number of leucocytes was seen for unstable angina (table 2). Also, the transit times showed considerable variation. Possibly, in the group of patients with unstable angina, a highly variable percentage of PMNs were activated and removed from the systemic circulation. It is noteworthy that in one study neutrophil elastase activity was more than twice as high in unstable angina than in $\mathrm{AMI}{ }^{30}$

\section{METHODOLOGICAL CONSIDERATIONS}

Differences in PMN pore transit times between the groups may have been underestimated in the present study for several reasons: (a) venous blood from the antecubital vein was studied, which reflects only a minor part of the changes in localised areas such as the coronary circulation-such a possibility has been suggested by simultaneous measurements of arterial and coronary sinus blood ${ }^{39}$; (b) potential activation of PMN along with the cell separation procedure or selection of activated cells during the centrifugation process cannot be ruled out, although there is no published evidence for this ${ }^{40} ;(c)$ the present CTA software classifies cells with filtration times greater than $100 \mathrm{~ms}$ as overrange cells, which are not included in the frequency analysis, possibly leading to a bias towards lower mean and median transit times. Differences between sub-populations could therefore be underestimated, because it is not possible to distinguish between cells with transit times just longer than $100 \mathrm{~ms}$ and those with much longer times; ( $d$ ) even though the time interval for inclusion was chosen rather early after onset of infarction, important immediate changes of the WBC populations may have been missed or diluted, because there are insufficient data available on the kinetics of WBC count and differential shifts soon after AMI.

\section{PATHOPHYSIOLOGICAL IMPLICATIONS}

Our results show that there was no accumulation of stiff PMN in the circulating blood in CHD including the early stages of AMI, while the WBC count was raised, especially in AMI and less so in unstable angina. These findings do not accord with earlier studies that showed increased flow resistance and a high degree of activation three days after AMI and reperfusion therapy. This discrepancy can be resolved if there is an increased cell turnover with a leftshifted PMN population that is not yet stiffened by activators washed out from the myocardium or that is less likely to be activated. The detection of a low level of activation could also be caused by trapping of highly activated cells in lungs or heart or by the insensitivity for pore-plugging cells of the technique used.

In summary, circulating PMNs from patients with AMI tested before the initiation of reperfusion therapy showed lower flow resistance than PMNs from controls (fig 2, table 2). The potential left shift of $P M N$ and a high turnover of WBC suggests that there may be a window for pharmacological interventions $^{41-43}$ aimed at suppressing leucocyte activation or bone marrow release-especially before, during, and after reperfusion therapy.

We are indebted to Dr M Boynard and R Guillet, Laboratoire de Biophysique Appliquée, Université René Descartes, Paris, France, for their valuable help with obtaining special CTA filte membranes for WBC experiments, and to Mrs Busch and Mrs Hoffmann, Department of Biomedical Statistics and Epidemiology, Technical University Munich, Germany, for thei expert help during the statistical analysis. We thank Dr D Krause, Kuratorium für Heimdialyse, Neu-Isenburg, Germany for providing us with the laboratory space to conduct this study.

This study was supported by a grant from the Deutsche Forschungsgemeinschaft PF 184/1-3.

1 Friedman GD, Klatsky AL, Siegelaub AB. The leukocyte count as a predictor of myocardial infarction. $N$ Engl $\mathcal{F}$ Med 1974;290:1275-8.

2 Gallitz T, Sandel P, Jahrmärker H, Rackwitz R, Haider M. Ein prognostischer Index bei akutem Myokardinfarkt Diskriminanzanalyse klinischer Parameter bei Klinikaufnahme. Dtsch med Wschr 1975;100:2517-23.

3 Lowe GDO, Machado SG, Krol WF, Barton WA, Forbes $\mathrm{CD}$. White blood cell count and hematocrit as predictors of coronary recurrence after myocardial infarction. Thromb Haemost 1985;54:700-3.

4 Romson JL, Hook BG, Kunkel SL, Abrams GD, Schork MA, Lucchesi BR. Reduction of the extent of ischemic myocardial injury by neutrophil depletion in the dog. myocardial injury by neutroph

5 Engler RL, Schmid-Schönbein GW, Pavelec RS. Leukocyte capillary plugging in myocardial ischemia and reperfusion in the dog. Am $\mathcal{F}$ Pathol 1983;111:98-111.

6 Mehta JL, Nichols WW, Mehta P. Neutrophils as potential participants in acute myocardial ischemia: relevance to reperfusion. $\mathcal{f} \mathrm{Am}$ Coll Cardiol 1988;11:1309-16.

7 Mehta J, Dinerman J, Mehta P, Saldeen TG, Lawson D, Donnelly WH, et al. Neutrophil function in ischemic heart disease. Circulation 1989;79:549-56.

8 Ernst E, Hammerschmidt DE, Bagge U, Dormandy JA.

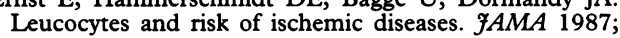
257:2318-24.

9 Dreyer WJ, Smith CW, Michael LH, Rossen RD, Hughes BJ, Entman ML, et al. Canine neutrophil activation by cardiac lymph obtained during reperfusion of ischemic myocardium. Circ Res 1989;65:1751-62.

10 Lucchesi BR, Mullane KM. Leukocytes and ischemiainduced myocardial injury. Annu Rev Pharmacol Toxicol 1986;26:201-24.

11 Anderson BO, Brown JM, Harken AH. Mechanisms of neutrophil-mediated tissue injury. $\mathcal{F}$ Surg Res 1991;51: $170-9$.

12 Dinerman JL, Mehta JL. Endothelial, platelet and leukocyte interactions in ischemic heart disease: insights into potential mechanisms and their clinical relevance. $₹ \mathrm{Am}$ potential mechanisms and their

13 Neumann F-J, Ott I, Gawaz M, Richardt G, Holzapfel H, Jochum $M$, et al. Cardiac release of cytokines and inflammatory responses in acute myocardial infarction. Circulation 1995;92:748-55.

14 Bagge U, Branemark P-I. White blood cell rheology. Adv Microcirc 1977;7:1-17.

15 Bauersachs RM, Hein HJ, Pfafferott C, Meiselman HJ. Veränderungen der Leukozyten-Rheologie bei akutem Myokardinfarkt; Mikropipetten-Untersuchungen von Granulozyten bei Patienten und gesunden Kontrollpersonen. In: Jung F, Kiesewetter H, Volger E, Ehrly A $\mathrm{M}$, eds. Aktuelles aus der klinischen Mikrozirkulation und Hämorheologie. Verhandlungsbericht der 9. Fahrestagung der Heutscheon Gesellschaft für Klinische Mikrozirkulation und Deutschen Gesellschaft für Klinische Mikrozirkulation und
Hämorheologie e.V. Berlin: Blackwell Wissenschaft, 1992:295-300.

16 Nash GB, Christopher B, Morris AJ, Dormandy JA. Changes in the flow properties of white blood cells afte acute myocardial infarction. Br Heart $\mathcal{F}$ 1989;62:329-34.

17 Wahi S, Kaul N, Ganguly NK, Varma S, Sharma BK Wahi PL. Neutrophil oxygen free radical production proportionates with the degree of myocardial ischemia. $\mathrm{Can} \mathcal{F}$ Cardiol 1991;7:229-33.

18 Radomski M, Herbaczynska-Cedro $\mathrm{K}$, Ceremuzynski L. Increased activity of circulating polymorphonuclear leukocytes in acute myocardial infarction. Int $\mathcal{f}$ Cardiol 1990;27:392-3.

19 Bell D, Jackson M, Nicoll JJ, Millar A, Dawes J, Muir AL Inflammatory response, neutrophil activation, and free radical production after acute myocardial infarction: radical production after acute myocardial in

20 Hansen PR, Kharazmi A. Effect of streptokinase on human neutrophil function in vitro and in patients with acute myocardial infarction. $f \mathrm{Mol}$ Cell Cardiol 1994;26: myocardial 
21 Hubbard WN. The systemic toxic response of patients to treatment with streptokinase streptodornase. $\mathcal{F}$ Clin Invest 1951;30:1171-4.

22 Nash GB, Jones JG, Mikita J, Dormandy JA. Methods and theory for analysis of flow of white cell subpopulations through micropore filters. $\mathrm{Br} \mathcal{F}$ Haematol 1988;70: 165-70.

23 Koutsouris D, Guillet $R$, Lelievre JC, Boynard $M$ Guillemin MT, Bertholom $P$, et al. Individual red blood cell transit times during flow through cylindrical micropores. Clin Hemorheology 1988;8:453-60.

24 Meiselman HJ, Bauersachs RM, Hein HJ, Koutsouris D Moessmer G, Nash GB. Rheological behavior of human PMN studied by micropipette aspiration and by micropore filtration. Monogr Atheroscler 1990;15:181-5.

25 Moessmer G, Meiselman HJ. Rheological behavior of white blood cells. In vitro and in vivo approaches: A new micropore filtration approach to the analysis of white cell rheology. Biorheology 1990;27:829-48.

26 Pécsvárady Z, Fisher TC, Darwin CH, Fabok A, Maqueda TS, Saad MF, et al. Decreased polymorphonuclear leukocyte deformability in NIDDM. Diabetes Care 1994; leukocyte

27 Pécsvárady Z, Fisher TC, Fabók A, Coates TD, Meiselman HJ. Kinetics of granulocyte deformability following exposure to chemotactic stimuli. Blood Cells 1992 18:333-52.

28 Radomski M, Herbaczynska-Cedro K, Ceremuzynski L Increased activity of circulating polymorphonuclear leukocytes in acute myocardial infarction. Int 7 Cardiol 1990;27:392-3.

29 Sylven C, Chen J, Bergstrom K, Bjorkman L, Wallin R, Saldeen T. Fibrin (ogen)-derived peptide $B$ beta $30-43$ is a sensitive marker of activated neutrophils during fibria sensitive marker of activated neutrophils during fibriHeart $₹ 1992 ; 124: 841-5$.

30 Dinerman JL, Mehta JL, Saldeen TG, Emerson S, Wallin $R$, Davda $R$, et al. Increased neutrophil elastase release in unstable angina pectoris and acute myocardial infarction. f Am Coll Cardiol 1990;15:1559-63.

31 Samuels AJ. Primary and secondary leucocyte changes following the intramuscular injection of epinephrine hydrochloride. $\mathcal{F}$ Clin Invest 1951;30:941-7.

32 Shandelya SML, Kuppusamy P, Weisfeldt ML, Zweier JL Evaluation of the role of polymorphonuclear leukocytes in myocardial reperfusion injury. Evidence for plasma-mediated leukocyte activation.
Circulation 1993;87:536-46.

33 Guarnieri C, Melandri G, Caldarera I, Scheda M, Ligabue A, Guizzardi S, et al. Reduced oxidative activity of circulating neutrophils in patients after myocardial infarction. Cell Biochem Funct 1990;8:157-62.

34 Neumann F-J, Ott I, Wilhelm A, Katus H, Tillmanns $H$ Schömig A. Release of chemoattractants and neutrophil activation in acute myocardial infarction immediately activation in acute myocardial infarction immediately after successful recanalization of the infarct

35 Anderson BO, Brown JM, Shanley PF, Bensard DD, Harken AH. Marginating neutrophils are reversibly adherent to normal lung endothelium. Surgery 1991;109: $51-61$.

36 Matthews SB, Campbell AK. Neutrophil activation after myocardial infarction. Lancet 1984;i:756-66.

37 Ito $B R$, Roth DM, Engler RL. Thromboxane $A_{2}$ and peptidoleukotrienes contribute to the myocardial ischemia and contractile dysfunction in response to intracoronary infusion of complement 45 in pigs. Circ Res 1990;66: 596-607.

38 Fuster V, Badimon L, Cohen M, Ambrose JA, Badimon JJ, Chesebro JH. Insights into the pathogenesis of acute

39 Neumann F-J, Richardt G, Schneider M, Ott I, Haupt H$\mathrm{M}$, Tillmanns $\mathrm{H}$, et al. Ischaemia-induced release of chemoattractants from human myocardium following coronary balloon angioplasty. Br Heart $\mathcal{F}$ 1993;70:27-34.

40 Nash GB, Jones JG, Mikita J, Christopher B, Dormandy JA. Effects of preparative procedures and of cell activation on flow of white cells through micropore filters. $\mathrm{Br} \mathcal{F}$ Haematol 1988;70:171-6.

41 Simpson PI Fantone JC Mickelson JK, Gallagher KP, Lucchesi BR. Identification of a time window for therapy to reduce experimental canine myocardial injury: suppression of neutrophil activation during 72 hours of pression of neutrophil activation du
reperfusion. Circ Res 1988;63:1070-9.

42 Tanaka M, Brooks SE, Richard VJ, FitzHarris GP, Stoler RC, Jennings RB, et al. Effect of anti-CD18 antibody on myocardial neutrophil accumulation and infarct size after ischemia and reperfusion in dogs. Circulation 1993;87: 526-35.

43 Hoshida S, Kuzuya T, Nishida M, Kim Y, Kitabatake A, Kamada $T$, et al. Attenuation of neutrophil function by inhibitors of arachidonate metabolism reduces the extent of canine myocardial infarction. Am $\mathcal{f}$ Cardiol 1989;63: $24 \mathrm{E}-28 \mathrm{E}$. 